\title{
Turizm Öğrencilerinin İş Güvencesizliği ve Kariyer İyimserliğinin Turizm Sektörü Algısını Etkilemesi Üzerine Bir Araştırma
}

\author{
Nükhet Adalet AKPULATa
}

\section{Özet}

Turizmin geliştiği ilk dönemlerde, turistik tesis sayısı önemli ölçüde artmış, gelen turist miktarı da buna paralel olarak yükseliş göstermiştir. Bu gelişmeler karşısında ilk olarak nitelikli eleman ihtiyacı baş göstermiştir. Turizm eğitimi veren eğitim kurumları açılarak bu ihtiyaç karşılanmaya çalışılmaktadır. Turizm istihdamı olumlu yönde etkilemesine rağmen, sektörün kendine ait özelliklerinden dolayı bazı farklılıklarda görülmektedir. Çalışmanın amacı, Ege Üniversitesi'nin Çeşme Turizm ve Otelcilik Yüksekokulu öğrencilerinin turizm sektörü algısında iş güvencesizliği ve kariyer iyimserliği değişkenlerinin rolünü incelemektir. Bir başka deyişle öğrencilerin turizm sektörü algılarının, iş güvencesizliği ve kariyer iyimserliği değişkenlerine göre değerlendirilmesidir. Araştırma 403 öğrenciye uygulanmıştır. Turizm Öğrencilerinin turizm sektörü algısıyla iş güvencesizliği arasında pozitif ve orta düzeyde bir ilişkinin olduğu, ancak turizm sektörü algısı ve kariyer iyimserliği arasında ise anlamlı bir ilişkinin olmadığı ortaya çıkarılmıştır. Ayrıca, seyahat işletmeciliği bölümünde okuyan öğrencilerin, konaklama işletmeciliği bölümünde okuyan öğrencilere göre ve 2 . sınıf öğrencilerinin de 4. sinıf öğrencilerine göre turizm sektörü algısı ölçeğine daha olumlu yanıtlar verdiği görülmüştür.
Anahtar Kelimeler

Turizm Öğrencileri

Turizm Sektörü Algısı

Kariyer İyimserliği

İş Güvencesizliği

Makale Hakkında

Geliş Tarihi: 05.10.2019

Kabul Tarihi: 13.03.2020

Doi: 10.18026/cbayarsos.629731

\section{Predicting The Tourism Students Perceptions on Tourism Sector Based on The Variables of Job İnsecurity and Career Optimism}

\begin{abstract}
In the first period that tourism developed, the number of touristic facilities increased as well as the number of incoming tourists. Following these developments, qualified personnel need appeared. For this reason, this need is trying to be met by opening schools that give tourism education. Although it affects the tourism employment positively, there are some differences due to the unique attributes of the sector. The aim of this study is to examine the perception of the students of Ege University, Çeşme School of Tourism and Hotel Management on tourism sector with the variables of job insecurity and career optimism. In other words, it is the interpretation of the students' perception on tourism sector in accordance with the variables of job insecurity and career optimism. Target population of the study includes 403 students. There was a positive and moderate relation between the perception of the students on tourism sector and job insecurity, however, there was no significant relation between the tourism sector perception and career optimism. Furthermore, students studying in Travel Management gave more positive answers compared to those that study in Accommodation Management and students in their $2^{\text {nd }}$ years gave more positive answers compared to $4^{\text {th }}$ year students according to the tourism sector perception scale.
\end{abstract}

Keywords

Tourism students

Tourism sector perception

Career Optimism

Job Insecurity

About Article

Received: 05.10.2019

Accepted: 13.03 .2020

Doi: 10.18026/cbayarsos.629731 


\section{Giriş}

Turizm, tüm dünya üzerinde hızla büyüyen önemli bir sektördür. Ülkelere ekonomik, sosyal ve kültürel anlamda pek çok artısı bulunmaktadır. Turizmin gelişmesi, geliştiği ülke bölge ya da destinasyonda olumlu ekonomik etkiler yaratır ve istihdama katkı sağlar. Her ne kadar istihdama olumlu katkı sağlasa da, çalışma saatleri, ücret politikası, mevsimlik olması gibi konular tartışma konusu olabilmektedir.

Hacıoğlu (2010), ücret yetersizliği, istihdamın mevsimlik olması, çalışma saatlerinin uzun ve işlerin yorucu olması gibi olumsuz koşullar nedeniyle turizm eğitimi alan nitelikli işgücünün büyük bir kısmının sektörde çalışmak istemediğini ve sektörden uzaklaştığını ifade etmektedir. Baum (2007), ağırlama endüstrisinin genellikle, düşük ücret, düşük iş garantisi, uzun çalışma saatleri, kişisel gelişim olanakları sınırlı ve sezonluk özellikleri olan bir meslek olarak bilindiğini ifade etmektedir. Dawson, Abbott ve Shoemaker (2011) ise, herkesin bu sektörde kariyer yapmak istemediğinin yüksek iş gören değişim oranından da görülebileceğini, ancak ağırlama endüstrisinin de etkileyici, hevesli ve adanmış iş görenlere ihtiyaç duyduğunu ifade etmektedir. Literatürde de ifade edildiği gibi, turizm sektörü çalışanlarının sektör algılarını olumsuz etkileyen faktörler mevcuttur. Bu çalışma içerisinde Savickas (1990) meslek seçiminin, bireyin ilgi, yetenek, değer, beklenti ve kişilik özelliklerine uygun olarak seçildiğinde kişinin ruh sağlığını mesleki ve özel hayatını olumlu yönde etkilediğini ve bireyin hayat kalitesi ve standardına olumlu yönde katkı sağladığını ifade etmektedir. Halıcı ve Delil (2003:22)'e göre, bir meslekle ilgili özelliklerin ilgili programlarda okuyan öğrenciler tarafından nasıl algılandığının belirlenmesi, o mesleğin toplumda nasıl algılandığını ve olması gerektiği şekilde anlaşılıp anlaşılmadığını göstermektedir. Bu açıklamalar ışı̆̆ında turizm eğitimi alan geleceğin turizmcilerinin, sektör algılarının pek çok faktörden etkilenebileceğini ve algılarının belirlenmesi gerektiğini söylememiz mümkündür. Çalışma turizm öğrencilerinin, iş güvencesizliği ve kariyer iyimserliğinin turizm sektörü algısını etkilemesi temeli üzerine kurulmaktadır.

Çalışmanın birinci bölümünde, iş güvencesizliği, kariyer iyimserliği ve turizm sektörü algısı kavramları açıklanmaktadır. İkinci bölümde ise beş tane hipotez yer almaktadır. Hipotezlerde, iş güvencesizliği ve kariyer iyimserliği değişkenlerine göre turizm sektörü alg1sı etkilenmekte midir? sorusuna cevap aranmakta, ayrıca öğrencilerin turizm sektörü algısı ölçeğine verdiği cevapların, cinsiyet, okudukları bölüm, okudukları sınıf ve sektörde çalışma sürelerine göre anlamlı bir farklılık gösterip göstermediği incelenmektedir. Yapılmış olan literatür taraması sonucunda, iş güvencesizliği ve kariyer iyimserliği kavramlarının aynı örneklem üzerinde çalışılmamış olması bu araştırmayı diğerlerinden ayırmaktadır.

\section{İş Güvencesizliği ve Kariyer İyimserliği Kavramları}

\section{Iş Güvencesizliğ i}

İş güvencesizliği tanımları incelendiğinde bazı noktaların ön plana çıtığı anlaşılmaktadır. Çakır (2007:119-120)'a göre, iş güvencesizliği, çalışılan işin devamlılığına engel olan her türlü yasal veya yasal olmayan örgütsel değişimler sonucunda ortaya çıkan, çalışanda belirsizlik düşüncesine bağlı olarak işini kaybetme kaygısı doğuran durumları kapsamaktadır. Diğer bir tanıma göre, algılanan iş güvencesizliğii, çalışanların işlerinin devamlılığı konusunda tehdit algılamaları olarak ifade edilebilir (Erlinghagen, 2008: 183). Heaney, Israel ve House (1994), iş güvencesizliğini "var olan işin sürekliliğine yönelik muhtemel bir tehdit algılaması" olarak tanımlamaktadır. 
İş güvencesizliğini inceleyen araştırmaların iki ana noktada toplandığını görülmektedir. İlk olarak, iş kaybı tehdidi ile yüzleşen çalışanlar için iş güvencesizliğinin sonuçları incelenmektedir. Bu çalışmaların yapıldığı bireyler, işten çıkarılmış ya da iş yerleri kapanan kişilerden oluşmaktadır. İkinci olarak ise, iş güvencesizliğinin kişisel tarafından algılanmasının etkileri değerlendirilmektedir (Özyaman, 2007:3). Karacaoğlu (2015) araştırması sonucunda, iş güvencesizliği ile işten ayrılma niyeti arasında pozitif yönlü yüksek düzeyde bir korelasyon ilişkisinin olduğunu belirtmektedir. Karacaoğlu ayrıca, iş güvencesizliğinin, kadınlarda erkeklere göre daha fazla olduğu, yaş grupları bakımından da gençlerin daha ileri yaştakilere göre daha yüksek iş güvencesizliği algısı içinde olduklarını, bekarların evlilere göre, ilköğretim mezunlarının daha yüksek eğitim düzeyine sahip olanlara göre daha fazla iş güvencesizliği algısı içinde olduklarını söylemektedir. Ayrıca, düşük gelir grubunda ve yönetici olmayanlarda iş güvencesizliğinin daha fazla hissedildiğini ifade etmektedir. Seçer (2009:330)'de, iş güvencesizliğinin çalışanlarda önemli bir stres kaynağ olduğunu ortaya koymaktadır. Boya ve diğerleri (2008) yaptıkları araştırma sonucunda, iş güvencesizliğinin kişilerin depresyona girmesine ve kaygı düzeylerinin yükselmesine neden olduğunu ortaya çıkarmaktadır. Burgard ve diğerleri (2012)'de yaptıkları araştırmada iş güvencesizliğinin fiziksel ve zihinsel sağlık problemlerinde artışa neden olduğunu belirtmektedir. Bakan ve Büyükbeşe (2004)'de benzer şekilde iş güvencesi değişkeni ile motivasyon, genel tatmin, iş tatmini, sosyal tatmin ve yöneticiden tatmin değişkenleri arasında istatistiksel açıdan anlamlı ilişkiler olduğunu söylemektedirler. Dursun ve Bayram (2013), cinsiyet değişkenine göre, çalışanların iş güvencesi algısı açısından anlamlı bir farklılık tespit edememekte, Poyraz ve Kama (2008) erkeklerin iş güvencesi algısının kadınlardan yüksek olduğunu ifade etmektedir. Dolayısıyla günümüzde işletmelerin en değerli varlığı olarak kabul edilen insan faktörünün işletme amaçları doğrultusunda en etkili şekilde yönlendirilebilmesi için iş güvencesi faktörünün göz önüne alınması gerektiğini söylememiz mümkündür.

Turizm sektörü mevsimlik özellik taşıması nedeniyle, çalışanlara önemli bir belirsizliği beraberinde getirmektedir. Diğer bir yandan sektördeki bazı işletmelerinde çalışanlarına karşı olumsuz politikalar izlemesi sonucu, iş güvencesizliği oldukça önemli bir konu haline gelmektedir.

\section{Kariyer Kavramı ve Kariyer İyimserliği}

Kariyer, kişinin çalışabileceği süreç içerisinde herhangi bir iş alanında sürekli deneyim kazanarak ve yeteneklerini geliştirerek ilerlemesi ve yükselmesi olarak tanımlanabilmektedir (Özgen v.d., 2002:179). Kariyer, çalışanların iş yaşamları süresince yaptıkları işleri, iş yaşamındaki gelişme ve ilerlemeleri içeren bir kavramdır (Bingöl, 2003: 245). Kişinin kariyeri, onun sadece sahip olduğu işler değil, iş yerinde kendisine verilen iş rolüne ilişkin beklenti, amaç, duygu ve arzularını gerçekleştirebilmesi için eğitilmesi ve böylece sahip olduğu bilgi, yetenek ve çalışma arzusu ile o işletmede ilerleyebilmesi anlamını taşımaktadır (Beach, 2010: 20). Patton ve Mcmahon (1999:4)'e göre kariyer, bireyin yaşamı boyunca üstlendiği bir takım görevle ilgili rolleri üzerine açıklanmaktadır. Bu roller, kişisel gelişim, kendini aşma, işsiz kalınan zaman, başarısız olma, staj dönemi, öğrencilik hayatındaki çalışmalar veya gönüllü olarak çalışma gibi bireyin olumlu ve olumsuz tüm aşamalarını kapsayan bir süreç olarak tanımlanmaktadır. Pehlivan (1994:37)'a göre, dikey kariyer, örgüt içi hiyerarşide üst basamaklara doğru ilerleme anlamında kullanılır ve biçimsel otorite ile ilişkilendirilmektedir. Can vd. (1998:163) ve Baruch, (2004:3)'a göre yatay kariyer ilerlemesi ise, mevcut konumundan 
memnun olan fakat bilgi, beceri ve yeteneğini geliştirmek ve aynı kademedeki farklı işlere yönelmek için yatay bir ilerleme gösteren çalışanları da kapsamaktadır (Patton ve McMahon, 2006: 4). Tanımlar genel olarak değerlendirildiğinde kariyeri bireyin hayatı boyunca mesleği ile ilgili olarak kendini geliştirmesi, yeniliklere ayak uydurabilmesi, deneyim kazanması şeklinde tanımlayabiliriz.

İyimserlik kavramı genel anlamıyla kişilerin yaşadıkları olaylar karşısında olumlu düşüncelerini besleyerek iyiye yorma halidir, bu kişilik özelliği olarak karşımıza çıksa da sonradan kazanılabilmektedir (Rottinghaus vd., 2005). Seligman (2006) iyimserliği, bireyin ileriki zamanlarda iyi şeyler olacağına duyduğu inanç olarak tanımlamakta ve yapılan faaliyetlerden elde edilen başarı ve doyum üzerinde büyük etkisi olduğunu vurgulamaktadır. Carver ve Scheier (1998)'e göre kötümser bireyler bir amaca ulaşma ve kişisel başarı için iyimser bireylere göre daha az çaba sarf etmektedirler. Bireylerin sahip olduğu olumlu bakış açısının çalıştıkları kurumların başarısına (Kluemper, Little ve DeGroot, 2009), bireysel anlamda bir amaç belirleme ve bu amaca bağlanmaya (Geers, Wellman ve Lassiter, 2009), akademik performansta ve yaşam memnuniyetinde artışa (Güler ve Emeç, 2006, Rand, 2009) neden olmaktadır. Rottinghaus vd, (2005) iyimser olan bireylerin bilgiyi ortaya koyma sürecinde daha esnek oldukları için oluşacak farklı ve yeni durumlar karşısında daha esnek davrandıklarını ve bulundukları ortama daha kolay uyum sağladıklarını belirtmektedir. Yazar hedeflerine ulaşmada iyimser yapıya sahip bireylerin daha başarılı olduğunu da ifade etmektedir.

Scheier ve Carver (1987)'a göre kariyer iyimserliği kişilerin kariyer planlarına ilişkin beklentilerinin gerçekleşmesi zor gibi görünse de olumlu bir bakış açısına sahip olmalarıdır. Bireylerin kariyer başarısını sağlayan değişkenlerden olan iyimserliğin "olumlu duygu, yüksek moral ve motivasyon, azim ve etkili problem çözme, akademik, askeri, mesleki başarı, popülerlik, sağlıklı uzun yaşam ve travmalardan kurtulmak" gibi faydaları bulunmaktadır (Gençoğlu vd., 2014). Kısaca kariyer iyimserliğine ise bireyin gelecekteki kariyer gelişimi ile ilgili olumlu sonuçlar elde edeceği beklentisi içinde olması ya da olayların en olumlu yönlerine vurgu yapması ve kariyer planlama sürecinde kendini rahat hissetmesidir diyebiliriz.

Turizm sektörü literatür çalışmasında da belirtildiği gibi, çalışanlar açısından zorlukları fazla olan bir sektör olarak belirlenmektedir. Hacığlu (2010), Baum (2007)'nin de belirttiği gibi, düşük ücret, fazla çalışma saatleri, mevsimlik olması, yükselme olanaklarının zorluğu gibi nedenler çalışanlar üzerinde olumsuz etkiler yaratmaktadır.

\section{Turizm Sektörü Algisl}

Turizm sektörün, siyasi ve ekonomik koşullara duyarlı olması sebebiyle işletmelerde doluluk oranı yıldan yıla ciddi değişimler gösterebilmekte ve durgunluk dönemlerinde istihdamda önemli daralmalar gözlenmektedir. Bunun yanında, turizmin zaman olarak yoğunlaşması da, yıl içinde belli dönemlerde işletmelerin faaliyetlerini artırmaktadır. Bu nedenle, işletmeler sezonluk personel çalıştırma yolunu tercih etmektedirler (Türkay ve Eryılmaz, 2010: 184). Kozak (1999:54)'a göre mevsimlik olma özelliği kariyer planlama konusunda işletmeleri ve çalışanları zor duruma sokmaktadır. Turizm sektörünün mevsimlik olma özelliğinden dolayı işletmeler geçici istihdama başvurmaktadır. O'Leary ve Deegan ( 2005: 421), turizm sektöründe geçici istihdam oranının diğer sektörlerden oldukça fazla olduğunu, çalışanların sürekli işsiz kalma tehlikesiyle karşı karşıya olduğunu, buna bağlı olarak çalışanların sağlıklı bir kariyer planlaması yapmadığını ifade etmektedir. Ayrıca yazarlar, bu nedenlerle sektörün sağlıklı bir istihdam yapısına sahip olamadığını, tüm bu olumsuzluklarında turizm 
sektörünün toplum tarafından olumsuz algılanmasına ve turizmin gelecek vaat eden bir iş kolu olarak görmemesine neden olduğunu söylemektedirler.

Turizmin emek-yoğun bir sektör olması nedeniyle, personelin eğitimi sektörün başarısı açısından önemlidir. Personelin eğitimi turizmde hizmet kalitesinin arttırılması ile doğrudan ilgili, hizmet kalitesindeki artış ise rekabette başarı ile doğrudan ilgilidir (Duman vd., 2006:51) $\mathrm{Bu}$ noktada turizm sektöründe eğitimli işgücündeki artışın büyük önem arz ettiği düşünülmektedir (Ulama, Batman ve Ulama, 2015:341). Türkiye'de mesleki turizm eğitimi, örgün ve yaygın olmak üzere iki şekilde gerçekleştirilmektedir. Örgün turizm eğitimi veren öğretim kurumları, ortaöğretim ve yükseköğretim düzeyinde mesleki turizm eğitimi veren okullardan oluşmaktadır. Yaygın turizm eğitimi ise, gerek resmi gerekse özel kurumlar tarafından verilen kısa süreli mesleki kurslar niteliğinde bir görünüm arz etmektedir (Ünlüönen ve Boylu, 2005:15). Hacioğlu (2010) ve Baum (2007)'un da belirttiği gibi turizm sektörünün, ücret yetersizliği, istihdamın mevsimlik olması, çalışma saatlerinin uzun ve işlerin yorucu olması düşük iş garantisi, kişisel gelişim olanakları gibi nedenler turizm sektöründe kariyer yapma düşüncesini olumsuz etkilemektedir. Bu sorunu ortaya çıkarmak ve çözüm bulunmasını sağlamak amacıyla araştırmalar yapılmaktadır.

Çatır ve Karaçor'un (2016) turizm fakültesi öğrencileri üzerine bir araştırma yapmış ve sonucunda, sınıf değişkenine göre kariyer planlama konusunda anlamlı farklılık görülmüştür. Öğrencilerin hazırlık sınıfına başladıklarında kariyer planlama konusunda istekli oldukları, fakat 2. Sınıfta öğrenim görmeye başladıklarında bu konuda olumlu düşüncelerini kaybettikleri sonucuna ulaşılmıştır.

Aymankuy ve Aymankuy (2013)'un birlikte yaptıkları çalışmada öğrencilerin, turizm sektöründeki çalışma saatlerinin düzensiz, sektörde çalışmanın diğer sektörlere göre daha yorucu, sosyal güvence imkanlarının yetersiz, tüm yıl boyunca çalışılabilecek bir iş bulmanın kolay olmadığı ifade edilirken, sektörde çalışmak eğlenceli ve zevkli olarak görülmektedir. Sektördeki ücret seviyesi diğer sektördeki ücretler ile aynı düzeyde algılanmakta ve sektördeki ücretler ile prim, bahşiş gibi ek ücretler yeterli ve tatmin edici görülmemektedir. Öğrenciler turizm sektörüne toplumun bakışını değerlendirirken, turizmin toplumda önemli ve itibarlı bir sektör olarak görülmediği, sektörde çalışmanın da toplumda saygınlığının olmadığı belirtmektedirler. Ancak lisans düzeyinde turizm eğitiminin bireye toplumsal itibar kazandırdığ $/$ /kazandıracağ sektörüne yönelik kariyer beklentileri ile ilgili değerlendirmelerinde, mezuniyet sonrası sektörde çalışmayı düşündükleri ancak, sektörün uzun yıllar çalışmak için uygun olmadığını belirtilmiştir.

Yapılan araştırmalar ve elde edilen literatür bilgilerine göre, turizm öğrencilerinin turizm sektörü algısında olumsuz değerlendirmeler olduğunu söylememiz mümkündür. Diğer bir ifade ile kariyer iyimserliklerinin düşük olduğunu söylememiz mümkündür.

\section{Araştırmanın Yöntemi}

Araştırmanın temel konusu, Ege Üniversitesi Turizm ve Otel İşletmeciliği Yüksekokulu öğrencilerinin iş güvencesizliği ve kariyer iyimserliğinin turizm sektörü algısına etkisinin belirlenmesidir. Bu amaçla nitel bir araştırma yapılmış ve anket tekniği kullanılmıştır. Araştırmanın temel konusuna bağlı olarak beş hipotez geliştirilmiştir.

H1:İş güvencesizliği ve Kariyer İyimserliği, Turizm Sektörü Algısını anlamlı bir şekilde etkilemektedir. 
H2:Öğrencilerin Turizm Sektörü Algısı Ölçeğine verdikleri cevaplar cinsiyet değişkenine göre farklılık göstermekte midir?

H3:Öğrencilerin Turizm Sektörü Algıları ile okudukları bölüm arasında anlamlı bir ilişki var midir?

H4:Öğrencilerin Turizm Sektörü Algıları ile okudukları sınıf arasında anlamlı bir ilişki var midir?

H5:Öğrencilerin Turizm Sektörü Algıları ve çalışma süreleri arasında anlamlı bir ilişki var midir?

\section{Araştırmanın Evren ve Örneklemi}

Araştırma evrenini, Ege Üniversitesi Turizm İşletmeciliği Yüksekokulu öğrencileri oluşturmaktadır. Kayıtlı 953 öğrenci bulunmaktadır. Sekaran(1992, 253)'a göre evrenin 950 olduğu durumda, örneklem 274 olmalıdır. Araştırma da 403 örneklem incelenmesi açısından oldukça yeterli olduğunu söylememiz mümkündür. Araştırmanın örneklemi ise kolayda örneklem yöntemi ile seçilmiştir. Kolayda örnekleme, ana kütle içerisinden seçilecek örnek kesimin araştırmacının yargılarınca belirlendiği tesadüfi olmayan örnekleme yöntemidir. Kolayda örneklemede veriler, ana kütleden en kolay, hızlı ve ekonomik şekilde toplanır (Aaker vd., 2007). Araştırma anket yöntemiyle gerçekleştirilmiştir. Öğrencilere toplamda 500 adet anket dağıtılmış eksik cevaplama, aynı şıkkı işaretleme ve araştırmaya katılmak istememe gibi nedenlerden 403 adet anket verisine ulaşılmıştır.

\section{Veri Toplama Araçları}

Kullanılan araştırma formu, literatür araştırması sonucu elde edilen bilgilerin yardımı ile oluşturulmuştur. Araştırma formu dört bölümden oluşmaktadır. İlk bölümde ankete katılacak kişilerin demografik özelliklerini belirleme amaçlı sorular, ikinci bölümde kariyerleri iyimserlikleri, üçüncü bölümde iş güvencesi hakkında düşünceleri, dördüncü bölümde ise turizm algılarının öğrenilmesine yönelik sorular sorulmuştur. İlk bölüm dokuz, ikinci bölüm on bir, üçüncü bölüm altı, dördüncü bölüm ise yirmi iki sorudan oluşmaktadır. Araştırmada 5'li likert tutum ölçeği kullanılmıştır.

Kariyer iyimserliği anketinde bulunan sorular Kalafat'(2012)'1n “Kariyer Geleceği Ölçeği (Kargel)'nden ölçeğinden faydalanılarak oluşturulmuş̧tur. Kargel ölçeği, kariyer uyumluluğu (11 madde), kariyer iyimserliği (11 madde) ve iş piyasasına ilişkin algılanan bilgi (3 madde) olmak üzere üç boyuttan oluşmaktadır. Araştırmada sadece kariyer iyimserliği boyutu kullanılmıştır. Kalafat'ın araştırmasında Kariyer İyimserliğinin alpha katsayısı 0,82 olarak hesaplanmıştır. Bu araştırmada ise alpha katsayısı 0,92' dir.

İş Güvencesizliği ile ilgili ifadeler ise, Karacaoğlu'nun (2015) araştırmasında kullandığı ölçektir. Karacaoğlu'nun araştırmasında iş güvencesizliği ölçeği tek boyutlu, altı maddeden oluşmakta ve alpha katsayısı 0,71 olarak belirlenmiştir. Bu araştırma da ise iş güvencesizliği ölçeğinin alpha katsayısı 0,86 olarak hesaplanmıştır.

Turizm Sektörü Algısı ölçeği ise, Duman, Tepeci ve Unur, (2006), Kuşluvan ve Kuşluvan, (2003), araştırmaları incelenerek uyarlanmıştır. Oluşturulan ölçek üç boyuttan oluşmaktadır. Alpha katsayıları sırasıyla, birinci boyut 0,81.5, ikinci boyut 0,87, üçüncü boyut 0,83.1'dir. Ölçeğin toplam güvenirlik katsayısı ise $0,90.6^{\prime}$ dır. 


\section{Turizm Sektörü Algısı Ölçeğinin Geçerlik ve Güvenilirliğinin Hesaplanması}

Araştırma içerisinde üç ölçek kullanılmaktadır. Kariyer iyimserliği ölçeği'nin ve İş güvencesizliği ölçeğinin geçerliğinin önceki araştırmalarda test edilmesi nedeni ile bu araştırma çerçevesinde hesaplanmamaktadır. Turizm sektörü algısı ölçeği ise literatür taraması sonrasında araştırmacı tarafından oluşturulması nedeni ile geçerlik ve güvenirlik analizleri yapılarak araştırmada yer verilmektedir.

Öncelikle Turizm Sektörü Algısı sonuçlarının maddelerinin ayırt ediciliğini test etmek amacıyla madde analizi yapılmıştır. Analiz sonuçlarına göre 0,445 ve 0,786 arasında olduğu görülmektedir. Madde ayırt ediciliğinde, 0,00 ile 0,20 arasında değer alan maddelerin iyi düzeyde ayırt edici olmadığı ve teste alınmaması gerektiği, 0,20 ile 0,30 arasında değer alan maddelerin orta düzeyde ayırt edici olduğu ve bu maddelerin düzeltildikten sonra teste alınması gerektiği, madde ayırt edicilik indeksinin 0,30 ' dan yüksek olan maddelerin ise iyi düzeyde ayırt edici olduğu ve bu maddelerin doğrudan teste alınması doğru kabul edilmektedir (Güler, 2012). Sonuçlara göre maddelerin 44'ün üzerinde olduğu görülmektedir. Sonuçlara göre maddeler ayırt edicidir ve ölçekte bulunmak için gereken şartları sağlamaktadırlar. (Tablo 1)

Tablo 1. Toplam Madde Korelasyonları

\begin{tabular}{|c|c|}
\hline Turizm Sektörü Algısı 1 & ,764 \\
\hline Turizm Sektörü Algısı 2 & ,757 \\
\hline Turizm Sektörü Algısı 3 & ,786 \\
\hline Turizm Sektörü Algısı 4 & ,601 \\
\hline Turizm Sektörü Algısı 5 & ,445 \\
\hline Turizm Sektörü Algısı 6 & ,666 \\
\hline Turizm Sektörü Algısı 7 & ,718 \\
\hline Turizm Sektörü Algısı 8 & ,565 \\
\hline Turizm Sektörü Algısı 9 & ,581 \\
\hline Turizm Sektörü Algısı 10 & ,469 \\
\hline Turizm Sektörü Algısı 11 & ,628 \\
\hline Turizm Sektörü Algısı 12 & ,627 \\
\hline Turizm Sektörü Algısı 13 & ,483 \\
\hline Turizm Sektörü Algısı 15 & 697 \\
\hline Turizm Sektörü Algısı 16 & ,688 \\
\hline Turizm Sektörü Algısı 18 & ,557 \\
\hline Turizm Sektörü Algısı 19 & ,638 \\
\hline Turizm Sektörü Algısı 20 &, 505 \\
\hline Turizm Sektörü Algısı 21 &, 578 \\
\hline Turizm Sektörü Algısı 22 & 607 \\
\hline
\end{tabular}

Büyüköztürk (2010), maddelerin ayırt ediciliğini belirlemek için, testin toplam puanlarına göre oluşturulan alt \%27 ve üst \%27'lik grupların madde ortalama puanları arasındaki farkların ilişkisiz t-testi kullanılarak sınanması yoluna başvurulabileceğini de ifade etmektedir. Yazar, gruplar arasında istenen yönde gözlenen farkların anlamlı çıkmasının, testin iç tutarlılığının bir göstergesi olarak değerlendirildiğini ifade etmektedir. Yapılan analiz sonucunda, tüm maddelerin anlamlı çıtı̆̆ görülmüştür. $(p=, 000, p \leq 001)$ yani anlamlı çıkmıştır. 
Turizm Sektörü Algısı ölçeğinin açıklayıcı faktör analizi yapılmıştır. Tavşancıl'a (2002) göre, faktör analizinde, örneklemden elde edilen verilerin yeterliğini belirlemek için Kaiser-MeyerOlkin (KMO) testi yapılmalıdır. Kaiser, bulunan değerin 1'e yaklaştıkça mükemmel, .50'nin altında ise kabul edilemeyeceğini göstermektedir. Verilerin temel bileşenler analizine uygunluğunu belirlemek için yapılan KMO değeri oldukça yüksek (.93) çıkmıştır. Kulaksızloğlu, Dilmaç, Ekşi ve Otrar (2003)'in belirttiği gibi, bu değerler, örneklem büyüklügünün ve elde edilen verilerin seçilen analiz için uygun ve yeterli olduğunu göstermektedir. Ayrıca, Tavşancıl'a (2002) göre faktör analizinde evrendeki dağılımın normal olması gerekir. Verilerin çok değişkenli normal dağılımdan gelip gelmediği ise Bartlett's testi ile test edilir. Barlett Küresellik testi anlamlılık düzeyi 0.000'dır. Bu testin anlamlı olmaması değişkenler arasında ilişki olmadığını göstermektedir. Ayrıca Barlett küresellik testi sonuçları incelendiğinde ki-kare $\left(\mathrm{X}^{2}{ }_{(190)}=5523,195, \mathrm{p}<.01\right)$ değerinin anlamlı olduğunu göstermektedir.

Tablo 2. Ölçeğin Faktör Analizine Uygunluğuna İlişkin Veriler

\begin{tabular}{llll}
\hline Kaiser-Mayer-Olkin (KMO) & &, 930 \\
& Ki-Kare & 5523,195 \\
Barlett Testi & Sd & 190 & \\
& & Sig. & \\
\hline
\end{tabular}

Geçerlilik bireyin ölçülmek istenen özelliğini ne derece doğru ölçtüğüyle ilgili bir kavramdır ve yapı geçerliliği de en çok tercih edilen geçerlilik sınıflandırmalarından birisidir (Büyüköztürk, 2010:167). Yapı geçerliliği, testin ölçülmek istenen davranış bağlamında soyut bir faktörü doğru şekilde ölçebilme derecesini göstermektedir. Bu amaçla faktör analizinden yararlanılmaktadır (Büyüköztürk, 2010:168) turizm sektörü algısı ölçeğinin, öz değer ve faktör yükleri de tablo yer almaktadır.

Turizm sektörü algısı ölçeğinin Cronbach's Alpha katsayısı 0.90.6'dır. Turizm Sektörü Algısı ölçeğinin alt boyutlarının cronbsch's alpha kat sayıları, çalışma koşulları .81,5, kariyer planı .,87, çalışan ilişkileri .,83,5' dir. Özdamar (2002:667) ve Tavşanel'e (2002) göre Cronbach Alpha katsayısı, 80-100 arası ise yüksek derecede güvenilir olduğunu gösterir. Ölçeğin tamamının ve alt boyutlarının yüksek derecede güvenilir olduğu anlaşılmaktadır. 
Tablo 3. Turizm Sektörü Algısı Ölçeği Faktörlerinin Faktör Yükleri, Öz değerleri, Açıkladıkları Varyans ve Toplam Açıklanan Varyansları

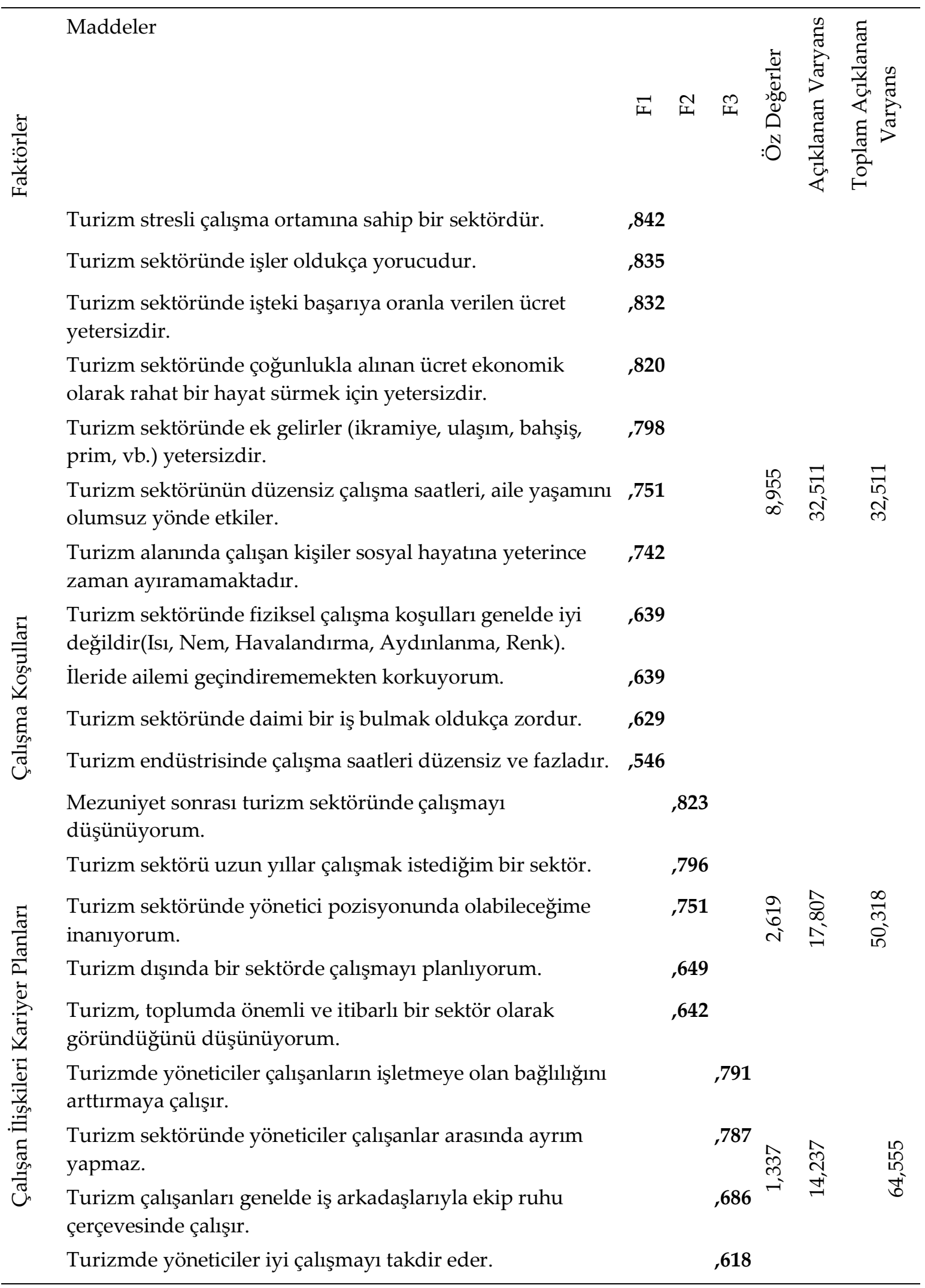




\section{Araştırma Bulguları}

Ege Üniversitesi Çeşme Turizm ve Otelcilik Yüksekokulu öğrencilerinin turizm çalışma koşulları, iş güvencesi ve kariyer beklentilerinin incelenmesi adına 403 adet anket uygulanmıştır. Araştırmada elde edilen veriler istatik programı ile analiz edilmiştir.

Tablo 4. Demografik Özelliklere Göre Frekans Dağılımı

\begin{tabular}{|c|c|c|c|c|c|}
\hline & F & $\%$ & & $F$ & $\%$ \\
\hline Cinsiyet & & & Medeni Hal & & \\
\hline Kadın & 172 & 42,7 & Evli & 2 & 0,5 \\
\hline Erkek & 231 & 57,3 & Bekar & 401 & 99,5 \\
\hline Eğitim Aldıkları Sınıf & & & Çalışılan Departmanlar & & \\
\hline 1.Sinif & 83 & 20,6 & Ön Büro & 172 & 26,2 \\
\hline 2.Sinif & 113 & 28,0 & Kat Hizmetleri & 95 & 14,5 \\
\hline 3.Sinif & 65 & 16,1 & Yiyecek-İçecek & 199 & 30,4 \\
\hline 4.Sinif & 142 & 35,2 & Mutfak & 61 & 9,3 \\
\hline Okunulan Bölüm & & & Seyahat Acentası & 73 & 11,1 \\
\hline Konaklama İşletmeciliği & 217 & 53,8 & Diğger & 54 & 8,2 \\
\hline Turizm Rehberliği & 99 & 24,6 & Çalışılan İşletme Sayısı & & \\
\hline Seyahat İşletmeciliği & 87 & 21,6 & 1 & 33 & 8,2 \\
\hline Yaşadıkları Şehir & & & 2 & 64 & 15,9 \\
\hline İstanbul & 68 & 16,9 & 3 & 74 & 18,4 \\
\hline İzmir & 69 & 17,1 & 4 ve daha fazla & 160 & 39,7 \\
\hline Diğer & 266 & 66,0 & Çalışmayan & 72 & 17,9 \\
\hline Doğum Yılı Dağılımı & & & Çalışma Süreleri & & \\
\hline 1991-1995 & 55 & 13,6 & Çalışmayan & 72 & 17,9 \\
\hline 1996 & 75 & 18,6 & 0-12 Ay & 133 & 33 \\
\hline 1997 & 99 & 24,6 & 13-24 Ay & 64 & 15,9 \\
\hline 1998 & 52 & 12,9 & 2 Yil ve üzeri & 134 & 33,3 \\
\hline 1999 & 79 & 19,6 & & & \\
\hline 2000 & 43 & 10,7 & & & \\
\hline
\end{tabular}

Araştırmaya katılanların demografik verileri Tablo 4' te yer almaktadır. Katılımcıların, \%42,7'si (172 kişi) kadın, \%57,3'ü (231 kişi) erkek, \%99,5 (401 kişi)'i bekardır. Sınıflara göre dağılımı ele alındığında, \%35,2 (142 kişi) ile 4. Sınıf, \%28 (113 kişi)'i 2.Sınıf, \%20,6 (83 kişi) 1. Sınıf, \%16,1 (65 kişi)'i de 3. Sınıf öğrencisidir. Araştırmaya katılan öğrencileri bölümlere göre değerlendirdiğimizde, konaklama işletmeciliği \%53,8 (217 kişi), Turizm Rehberliği \%24,6 (99 kişi), Seyahat İşletmeciliği ise \%21,6 (87 kişi) olduğu anlaşılmaktadır.

\section{Araştırma Analizleri}

Araştırma formunda kariyer iyimserliği (11 Madde) ölçeğinin, cevaplarının ortalamaları ve standart sapma değerleri tablolarda verilmektedir. Araştırmada 5'li likert ölçeği çerçevesinde incelendiğinden ortalaması 3.00 'dan büyük olan ifadeler ve faktörler olumlu yönde bir katılımı, 3.00'ın altında olanlar ise daha düşük derecede bir katılımı göstermektedir. 
Kariyer İyimserliği Ölçeğinin ortalamaları incelediğimizde en yüksek derecede olumlu katılımın, "İleride mesleğimde başarılı olacağımdan eminim" (3,79), en düşük katılımın "Doğru mesleği bulmak oldukça zordur" $(2,68)$ ifadesine olduğu görülmektedir. Bu sonuçlar bireylerin meslek seçimi ve başarısı konusunda kendilerine güvendiklerini göstermektedir dememiz mümkündür.

Tablo 5. Kariyer İyimserliği Yüzde Dağılımı Ortalama ve Standart Sapma Değerleri

\begin{tabular}{|c|c|c|c|c|c|c|c|c|}
\hline & 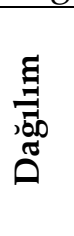 & 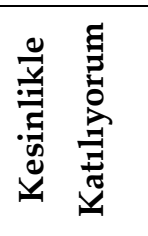 & 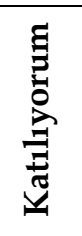 & 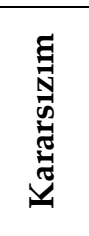 & 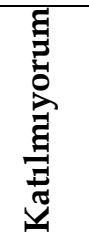 & 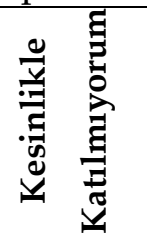 & $\frac{\widetilde{J}}{\tilde{\Xi}}$ & 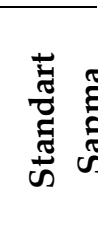 \\
\hline \multirow{2}{*}{$\begin{array}{l}\text { Kariyerim hakkında düşündüğüm } \\
\text { zamanlarda heyecanlanırım. }\end{array}$} & $\mathrm{F}$ & 88 & 143 & 87 & 57 & 28 & \multirow{2}{*}{3,51} & \multirow{2}{*}{1,17} \\
\hline & $\%$ & 21,8 & 35,5 & 21,6 & 14,1 & 6,9 & & \\
\hline \multirow{2}{*}{$\begin{array}{l}\text { Kariyerim ile ilgili düşünmek bana } \\
\text { ilham verir. }\end{array}$} & $\mathrm{F}$ & 90 & 146 & 87 & 55 & 25 & \multirow{2}{*}{3,54} & \multirow{2}{*}{1,15} \\
\hline & $\%$ & 22,3 & 36,2 & 21,6 & 13,6 & 6,2 & & \\
\hline \multirow{2}{*}{$\begin{array}{l}\text { Kariyerim hakkında düşünmek canımı } \\
\text { sıkar. }\end{array}$} & $\mathrm{F}$ & 67 & 115 & 90 & 83 & 48 & \multirow{2}{*}{3,17} & \multirow{2}{*}{1,26} \\
\hline & $\%$ & 16,6 & 28,5 & 22,3 & 20,6 & 11,9 & & \\
\hline \multirow{2}{*}{$\begin{array}{l}\text { Benim için kariyer hedefleri belirlemek } \\
\text { oldukça zordur. }\end{array}$} & $\mathrm{F}$ & 75 & 96 & 86 & 92 & 54 & \multirow{2}{*}{3,11} & \multirow{2}{*}{1,31} \\
\hline & $\%$ & 18,6 & 23,8 & 21,3 & 22,8 & 13,4 & & \\
\hline \multirow{2}{*}{$\begin{array}{l}\text { Yeteneklerimi özel bir kariyer planıyla } \\
\text { ilişkilendirmekte zorlanıyorum. }\end{array}$} & $\mathrm{F}$ & 59 & 103 & 91 & 90 & 60 & \multirow{2}{*}{3,02} & \multirow{2}{*}{1,28} \\
\hline & $\%$ & 14,6 & 25,6 & 22,6 & 22,3 & 14,9 & & \\
\hline \multirow{2}{*}{ Mesleki ilgilerimin farkındayım. } & F & 128 & 128 & 73 & 43 & 31 & \multirow{2}{*}{3,69} & \multirow{2}{*}{1,23} \\
\hline & $\%$ & 31,8 & 31,8 & 18,1 & 10,7 & 7,7 & & \\
\hline \multirow{2}{*}{$\begin{array}{l}\text { Kariyer hayallerimi takip etme } \\
\text { konusunda oldukça kararlı ve } \\
\text { azimliyim. }\end{array}$} & $\mathrm{F}$ & 113 & 121 & 82 & 57 & 30 & \multirow[b]{2}{*}{3,57} & \multirow[b]{2}{*}{1,24} \\
\hline & $\%$ & 28 & 30 & 20,3 & 14,1 & 7,4 & & \\
\hline \multirow{2}{*}{$\begin{array}{l}\text { İleride mesleğimde başarılı } \\
\text { olacağımdan eminim. }\end{array}$} & $\mathrm{F}$ & 134 & 134 & 71 & 45 & 19 & \multirow{2}{*}{3,79} & \multirow{2}{*}{1,15} \\
\hline & $\%$ & 33,3 & 33,3 & 17,6 & 11,2 & 4,7 & & \\
\hline \multirow{2}{*}{ Doğru mesleği bulmak oldukça zordur. } & $\mathrm{F}$ & 46 & 94 & 60 & 92 & 111 & \multirow{2}{*}{2,68} & \multirow{2}{*}{1,38} \\
\hline & $\%$ & 11,4 & 23,3 & 14,9 & 22,8 & 27,5 & & \\
\hline \multirow{2}{*}{$\begin{array}{l}\text { Kariyerimi planlamak son derece doğal } \\
\text { bir iştir. }\end{array}$} & $\mathrm{F}$ & 100 & 122 & 119 & 39 & 23 & \multirow{2}{*}{3,58} & \multirow{2}{*}{1,13} \\
\hline & $\%$ & 24,8 & 30,3 & 29,5 & 9,7 & 5,7 & & \\
\hline \multirow{2}{*}{$\begin{array}{l}\text { Kariyerimle ilişkili doğru kararları } \\
\text { alacağıma eminim. }\end{array}$} & $\mathrm{F}$ & 116 & 117 & 103 & 36 & 31 & \multirow{2}{*}{3,62} & \multirow{2}{*}{1,20} \\
\hline & $\%$ & 28,8 & 29,0 & 25,6 & 8,9 & 7,7 & & \\
\hline
\end{tabular}

"Mesleki ilgilerimin farkındayım" (3,69) ifadesi ikinci en yüksek katılımın olduğu ifade olması açısından önem taşımaktadır. Bu ifadeden araştırmaya katılan öğrencilerin, çalışacakları meslekle ilgili olarak hangi alanda ilgili olduklarını, dolayısıyla turizm sektörünün hangi alanında çalışacaklarına karar verdiklerini söylememiz mümkündür. Ölçekte yer alan diğer ifadeleri ve ortalamaları, "Kariyerimle ilişkili doğru kararları alacağıma eminim" $(3,62)$, "Kariyerimi planlamak son derece doğal bir iştir." $(3,58)$ "Kariyer hayallerimi takip etme konusunda oldukça kararlı ve azimliyim" (3,57), "Kariyerim ile ilgili düşünmek bana ilham verir" $(3,54)$, "Kariyerim hakkında düşündüğüm zamanlarda heyecanlanırım" $(3,51)$ olarak 
dağılım göstermektedir. Bu ifadelerin ortalamalarının 3.00'ın üzerinde olması da olumlu yönde katılımı göstermektedir. Araştırmaya katılan öğrencilerin kariyer iyimserliklerinin olumlu olduğu sonucunu çıkarmamız mümkündür.

Tablo 6. İş Güvencesizliği Yüzde Dağılımı, Ortalama ve Standart Sapma Değerleri

\begin{tabular}{|c|c|c|c|c|c|c|c|c|}
\hline & 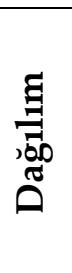 & 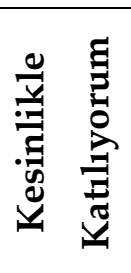 & 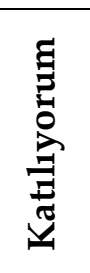 & 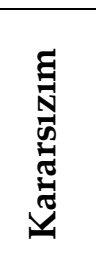 & E & 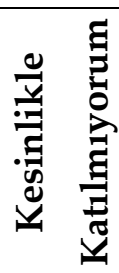 & 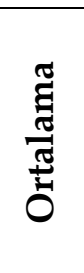 & 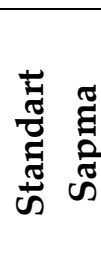 \\
\hline \multirow{2}{*}{$\begin{array}{l}\text { Gelecekte sektördeki } \\
\text { pozisyonumu oldukça sağlam } \\
\text { görüyorum. }\end{array}$} & $\mathrm{F}$ & 76 & 123 & 119 & 55 & $30^{\prime}$ & \multirow[b]{2}{*}{3,39} & \multirow[b]{2}{*}{1,15} \\
\hline & $\%$ & 18,9 & 30,5 & 29,5 & 13,6 & 7,4 & & \\
\hline \multirow{2}{*}{$\begin{array}{l}\text { Alanımdaki kariyerimi tahmin } \\
\text { edebiliyorum. }\end{array}$} & $\mathrm{F}$ & 90 & 131 & 92 & 51 & 39 & \multirow{2}{*}{3,45} & \multirow{2}{*}{1,23} \\
\hline & $\%$ & 22,3 & 32,5 & 22,8 & 12,7 & 9,7 & & \\
\hline \multirow{2}{*}{$\begin{array}{l}\text { Eğitim aldığım mesleğimi } \\
\text { ilerleyen yıllarda da yapmayı } \\
\text { düşünüyorum. }\end{array}$} & $\mathrm{F}$ & 84 & 95 & 165 & 28 & 31 & \multirow[b]{2}{*}{3,42} & \multirow[b]{2}{*}{1,12} \\
\hline & $\%$ & 20,8 & 23,6 & 40,9 & 6,9 & 7,7 & & \\
\hline \multirow{2}{*}{$\begin{array}{l}\text { Mesleğimle ilgili geleceğim } \\
\text { konusunda şüpheliyim. }\end{array}$} & $\mathrm{F}$ & 63 & 98 & 97 & 89 & 56 & \multirow{2}{*}{3,05} & \multirow{2}{*}{1,28} \\
\hline & $\%$ & 15,6 & 24,3 & 24,1 & 22,1 & 13,9 & & \\
\hline \multirow{2}{*}{$\begin{array}{l}\text { Mesleğimde geleceğimin nasıl } \\
\text { olacağı bilinemez. }\end{array}$} & $\mathrm{F}$ & 47 & 102 & 78 & 110 & 66 & \multirow{2}{*}{2,88} & \multirow{2}{*}{1,28} \\
\hline & $\%$ & 11,7 & 25,3 & 19,4 & 27,3 & 16,4 & & \\
\hline \multirow{2}{*}{$\begin{array}{l}\text { Bulunduğum meslekte } \\
\text { geleceğim garanti altındadır. }\end{array}$} & $\mathrm{F}$ & 79 & 78 & 104 & 85 & 57 & \multirow{2}{*}{3,09} & \multirow{2}{*}{1,32} \\
\hline & $\%$ & 19,6 & 19,4 & 25,8 & 21,1 & 14,1 & & \\
\hline
\end{tabular}

İş güvencesizliği ölçeğinin yüzde dağılımı, ortalama ve standart sapma değerleri Tablo 6'da gösterilmektedir. Altı madde içerisinde en yüksek katılımın "Alanımdaki kariyerimi tahmin ediyorum" $(3,45)$, en düşük katılım ise, "Mesleğimde geleceğimin nasıl olacağı bilinemez" $(2,88)$ ifadelerine yapıldığı anlaşılmaktadır. Bu iki ifadeye verilen cevaplar birbirini destekler şekilde dağılım göstermektedir. "Eğitim aldığım mesleğimi ilerleyen yıllarda da yapmayı düşünüyorum." $(3,42)$ ifadesinde öğrencilerin okudukları bölümde çalışmaya olumlu baktıklarını, "Gelecekte sektördeki pozisyonumu oldukça sağlam görüyorum." $(3,39)$ ifadesi ise işleri ile ilgili kendilerine güven duyduklarını gösterirken, "Mesleğimle ilgili geleceğim konusunda şüpheliyim" $(3,05)$ ifadesine katılımın diğer ifadelerden düşük olmasına rağmen 3.00'1n üzerinde olması dikkat çekicidir. Bunun nedeni olarak turizm sektörünün son yıllarda yaşadığı olumsuzluklar düşünülebilir. Ayrıca, İş güvencesizliği ölçeğine verilen cevaplar, Kariyer İyimserliği Ölçeğini destekler şekilde dağılım göstermektedir.

Tablo 7. Turizm Sektörü Algısı Yüzde Dağılımı, Ortalama ve Standart Sapma Değerleri.

\begin{tabular}{|c|c|c|c|c|c|c|c|c|}
\hline 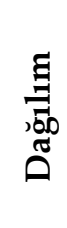 & 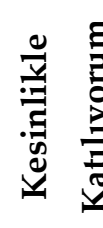 & 疍 & 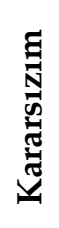 & 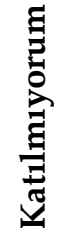 & 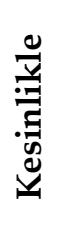 & 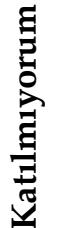 & 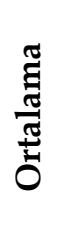 & 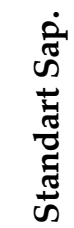 \\
\hline
\end{tabular}




\begin{tabular}{|c|c|c|c|c|c|c|c|c|}
\hline \multirow{2}{*}{$\begin{array}{l}\text { Turizm sektöründe işteki başarıya } \\
\text { oranla verilen ücret yetersizdir. }\end{array}$} & $\mathrm{F}$ & 37 & 88 & 60 & 92 & 126 & \multirow{2}{*}{2,54} & \multirow{2}{*}{1,36} \\
\hline & $\%$ & 9,2 & 21,8 & 14,9 & 22,8 & 31,3 & & \\
\hline \multirow{2}{*}{$\begin{array}{l}\text { Turizm sektöründe ek gelirler } \\
\text { (ikramiye, ulaşım, bahşiş, prim, vb.) } \\
\text { yetersizdir. }\end{array}$} & $\mathrm{F}$ & 33 & 93 & 81 & 90 & 106 & \multirow[b]{2}{*}{2,64} & \multirow[b]{2}{*}{1,30} \\
\hline & $\%$ & 8,2 & 23,1 & 20,1 & 22,3 & 26,3 & & \\
\hline \multirow{2}{*}{$\begin{array}{l}\text { Turizm sektöründe çoğunlukla alınan } \\
\text { ücret ekonomik olarak rahat bir hayat } \\
\text { sürmek için yetersizdir. }\end{array}$} & $\mathrm{F}$ & 34 & 82 & 84 & 91 & 112 & \multirow{2}{*}{2,59} & \multirow{2}{*}{1,30} \\
\hline & $\%$ & 8,4 & 20,3 & 20,8 & 22,6 & 27,8 & & \\
\hline \multirow{2}{*}{$\begin{array}{l}\text { İleride ailemi geçindirememekten } \\
\text { korkuyorum. }\end{array}$} & $\mathrm{F}$ & 47 & 93 & 79 & 91 & 93 & \multirow{2}{*}{2,77} & \multirow{2}{*}{1,34} \\
\hline & $\%$ & 11,7 & 23,1 & 19,6 & 22,6 & 23,1 & & \\
\hline \multirow{2}{*}{$\begin{array}{l}\text { Turizm endüstrisinde çalışma saatleri } \\
\text { düzensiz ve fazladır. }\end{array}$} & $\mathrm{F}$ & 5 & 11 & 147 & 116 & 124 & \multirow{2}{*}{2,14} & \multirow{2}{*}{0,93} \\
\hline & $\%$ & 1,2 & 2,7 & 36,5 & 28,8 & 30,8 & & \\
\hline \multirow{2}{*}{$\begin{array}{l}\text { Turizm sektöründe işler oldukça } \\
\text { yorucudur. }\end{array}$} & $\mathrm{F}$ & 18 & 55 & 109 & 110 & 111 & \multirow{2}{*}{2,40} & \multirow{2}{*}{1,15} \\
\hline & $\%$ & 4,5 & 43,6 & 27,0 & 27,3 & 27,5 & & \\
\hline \multirow{2}{*}{$\begin{array}{l}\text { Turizm stresli çalışma ortamına sahip } \\
\text { bir sektördür. }\end{array}$} & $\mathrm{F}$ & 26 & 69 & 93 & 99 & 116 & \multirow{2}{*}{2,47} & \multirow{2}{*}{1,24} \\
\hline & $\%$ & 6,5 & 17,1 & 23,1 & 24,6 & 28,8 & & \\
\hline \multirow{2}{*}{$\begin{array}{l}\text { Turizm daimi bir iş bulmak oldukça } \\
\text { zordur. }\end{array}$} & $\mathrm{F}$ & 41 & 87 & 118 & 95 & 62 & \multirow{2}{*}{2,87} & \multirow{2}{*}{1,20} \\
\hline & $\%$ & 10,2 & 21,6 & 29,3 & 23,6 & 15,4 & & \\
\hline \multirow{2}{*}{$\begin{array}{l}\text { Turizm sektöründe fiziksel çalışma } \\
\text { koşulları genelde iyi değildir.(1sı, nem, } \\
\text { havalandırma). }\end{array}$} & $\mathrm{F}$ & 44 & 85 & 119 & 109 & 46 & \multirow[b]{2}{*}{2,93} & \\
\hline & $\%$ & 10,9 & 21,1 & 29,5 & 27,0 & 11,4 & & 1,17 \\
\hline Turizm sektöründe yöneticiler çalışanlar & $\mathrm{F}$ & 47 & 72 & 85 & 102 & 97 & 2,67 & 1,32 \\
\hline arasında ayrım yapmaz. & $\%$ & 11,7 & 17,9 & 21,1 & 25,3 & 24,1 & & \\
\hline Turizmde yöneticiler çalışanların & $\mathrm{F}$ & 75 & 94 & 116 & 74 & 44 & & \\
\hline $\begin{array}{l}\text { işletmeye olan bağ llı̆ğını arttırmaya } \\
\text { çalışır. }\end{array}$ & $\%$ & 18,6 & 23,3 & 28,8 & 18,4 & 10,9 & 3,20 & 1,24 \\
\hline Turizm çalışanları genelde iş & $\mathrm{F}$ & 80 & 124 & 107 & 67 & 25 & & \\
\hline $\begin{array}{l}\text { arkadaşlarıyla ekip ruhu çerçevesinde } \\
\text { çalışır. }\end{array}$ & $\%$ & 19,9 & 30,8 & 26,6 & 16,6 & 6,2 & 3,41 & 1,16 \\
\hline Turizmde yöneticiler iyi çalışmayı & $\mathrm{F}$ & 71 & 140 & 113 & 50 & 29 & 3.43 & 1.13 \\
\hline takdir eder. & $\%$ & 17,6 & 34,7 & 28,0 & 12,4 & 7,2 & נדונ, & 1,1 \\
\hline Turizm sektöründe çalışanların genelde & $\mathrm{F}$ & 24 & 90 & 131 & 94 & 64 & 270 & 112 \\
\hline eğitim seviyesi düşüktür & $\%$ & 6,0 & 22,3 & 32,5 & 23,3 & 15,9 & 2,13 & 1,10 \\
\hline Turizm sektörünün düzensiz çalışma & $\mathrm{F}$ & 11 & 64 & 107 & 104 & 117 & & \\
\hline $\begin{array}{l}\text { saatleri, aile yaşamını olumsuz yönde } \\
\text { etkiler. }\end{array}$ & $\%$ & 2,7 & 15,9 & 26,6 & 25,8 & 29,0 & 2,37 & 1,13 \\
\hline Turizm alanında çalışan kişiler sosyal & $\mathrm{F}$ & 18 & 66 & 111 & 110 & 98 & & \\
\hline $\begin{array}{l}\text { hayatına yeterince } \\
\text { ayıramamaktadır. }\end{array}$ & $\%$ & 4,5 & 16,4 & 27,5 & 27,3 & 24,3 & 2,49 & 1,15 \\
\hline Mezuniyet sonrası turizm sektöründe & $\mathrm{F}$ & 76 & 144 & 91 & 45 & 47 & 3,38 & 1,24 \\
\hline çalışmayı düşünüyorum. & $\%$ & 18,9 & 35,7 & 22,6 & 11,2 & 11,7 & 0,30 & 1,24 \\
\hline Turizm sektörü uzun yıllar çalışma & $\mathrm{F}$ & 76 & 90 & 110 & 67 & 60 & 3,13 & 1,31 \\
\hline istediğim bir sektör. & $\%$ & 18,9 & 22,3 & 27,3 & 16,6 & 14,9 & 0,10 & 1,01 \\
\hline & $\mathrm{F}$ & 115 & 98 & 129 & 36 & 25 & 3,60 & 1,16 \\
\hline
\end{tabular}




\begin{tabular}{|c|c|c|c|c|c|c|c|c|}
\hline $\begin{array}{l}\text { Turizm sektöründe } \begin{array}{r}\text { yönetici } \\
\text { pozisyonunda } \\
\text { inaniyorum. }\end{array} \\
\text { olabileceğime }\end{array}$ & $\%$ & 28,5 & 24,3 & 32 & 8,9 & 6,2 & & \\
\hline \multirow{2}{*}{$\begin{array}{l}\text { Turizm, toplumda önemli ve itibarlı bir } \\
\text { sektör olarak göründüğünü } \\
\text { düşünüyorum. }\end{array}$} & $\mathrm{F}$ & 62 & 93 & 129 & 63 & 56 & \multirow[b]{2}{*}{3,10} & \multirow[b]{2}{*}{1,24} \\
\hline & $\%$ & 15,4 & 23,1 & 32,0 & 15,6 & 13,9 & & \\
\hline \multirow{2}{*}{$\begin{array}{l}\text { Turizm dışında bir sektörde çalışmayı } \\
\text { planlıyorum. }\end{array}$} & $\mathrm{F}$ & 36 & 73 & 132 & 86 & 76 & \multirow{2}{*}{2,76} & \multirow{2}{*}{1,20} \\
\hline & $\%$ & 8,9 & 18,1 & 32,8 & 21,3 & 18,9 & & \\
\hline
\end{tabular}

Tablo 7'de ise araştırma süreci içerisinde geliştirilen Turizm sektörü algısı ölçeğinin yüzde dağılımları, ortalama ve standart sapma değerleri verilmektedir. Bu ölçekte araştırmaya katılan kişilerin turizm sektörü algısı incelenmiştir. Araştırma sonuçlarına göre en yüksek dereceli olumlu katılımın "Turizm sektöründe yönetici pozisyonunda olabileceğime inanıyorum." $(3,60)$ ifadesine en düşük derecede olumlu katılım ise "Turizm endüstrisinde çalışma saatleri düzensiz ve fazladır." (2,14) ifadesine olmuştur. Araştırmaya katılan öğrenciler, mesleklerinde üst kademeye ulaşabileceklerini düşünmektedirler. Ayrıca turizm endüstrisinde çalışma saatlerinin düzensiz ve fazla olduğunu düşünmemektedirler. "Turizm sektöründe işteki başarrya oranla verilen ücret yetersizdir." $(2,54)$ ifadesine verilen cevaplara göre turizm sektöründe yeterli seviyede ücret verildiğini düşünmektedirler. Ayrıca katılımcılar "Turizm sektöründe ek gelirler (ikramiye, ulaşım, bahşiş, prim, vb.) yetersizdir." $(2,64)$ ifadesine de düşük katılım göstermektedirler. Diğer bir ifade ile ek gelirlerin yeterli olduğunu düşündükleri sonucuna varılmaktadır. Bu madde "Turizm sektöründe çoğunlukla alınan ücret ekonomik olarak rahat bir hayat sürmek için yetersizdir." $(2,59)$ maddesine verilen cevabı destekler nitelikte olup ücret ve ek gelirlerin yeterli olduğu sonucunu pekiştirmektedir. Diğer ortalamaları incelediğimizde, “Turizm sektöründe işler oldukça yorucudur." $(2,40)$ ve "Turizm stresli çalışma ortamına sahip bir sektördür." $(2,47)$ ifadelerine verdikleri cevaplar olumsuz katılımı ifade etmektedir. Katılımcılar çalışma koşullarının stresli ve yorucu olmadığını konusunda ağırlıklı bir düşünceye sahiptirler. "Turizm çalışanları genelde iş arkadaşlarıyla ekip ruhu çerçevesinde çalışır." $(3,41)$ ve "Turizmde yöneticiler iyi çalışmayı takdir eder." (3,43) maddelerine verilen cevaplar olumlu yönde katılımı göstermektedir. Katılımcıların turizm sektöründe bireylerin iş arkadaşlarıyla ekip ruhu çerçevesinde çalıştıkları düşüncesine hakim oldukları anlaşılmaktadır. Bu sonucun en önemli sebebi olarak, turizm sektörünün tam anlamıyla bir ekip işi olması olarak gösterilebilir. Ayrıca katılımcılar, yöneticilerin yeterli ve iyi çalışmayı takdir ettiklerini düşünmektedir. Araştırma kapsamında katılımcılar, "Turizm sektörünün düzensiz çalışma saatleri, aile yaşamını olumsuz yönde etkiler." $(2,37)$ ve "Turizm alanında çalışan kişiler sosyal hayatına yeterince zaman ayıramamaktadır." (2,49) ifadelerine düşük katılım göstermektedirler. Buradan katılımcıların, turizmde çalışan kişilerin aile ve sosyal hayatına yeterince zaman ayırabileceği kanısını taşıdıklarını söylemek mümkündür.

\section{Çoklu Doğrusal Regresyon Analizi}

Araştırmada kullanılan ölçeklerin yüzde dağılımı, ortalama ve standart sapmalarının değerlendirilmesinden sonra, Turizm Sektörü Algısı, Kariyer İyimserliği ve İş Güvencesizliği arasındaki ilişkileri belirlemek amacıyla regresyon analizi yapılmıştır. İlişki için oluşturulan hipotezler aşağıdaki gibidir.

H1:İş güvencesizliği ve Kariyer İyimserliği Turizm Sektörü Algısını anlamlı bir şekilde etkilemektedir. 
İş güvencesizliği ve kariyer iyimserliği değişkenlerine göre Turizm Sektörü Algısının etkilenmesine ilişkin regresyon analizi sonuçları Tablo 8'de verilmiştir.

Etkileyen değişkenlerle bağımlı (etkilenen) değişken arasındaki ikili ve kısmi korelasyonlar incelendiğinde, Turizm sektörü Algısıyla, iş güvencesizliği arasında pozitif ve orta düzeyde bir ilişkinin ( $\mathrm{r}=0.65 \mathrm{p}<.000)$ olduğu, ancak diğer değişkenler kontrol edildiğinde de iki değişken arasındaki korelasyonun $(\mathrm{r}=0,38)$ olarak hesaplandığı görülmektedir. Turizm sektörü algısı ve kariyer iyimserliği arasında anlamlı bir ilişki incelendiğinde ise anlamlı bir ilişkinin olmadığı ortaya çıarılmıştır. $(\mathrm{p}=, 322)$.

\begin{tabular}{llccccccc}
\hline \multicolumn{7}{l}{ Tablo 8. Turizm Sektörü Algısının Etkilenmesine İlişkin Çoklu Regresyon Analizi. } \\
\hline Etkilenen & Etkileyen & B & SS & Beta & T & P & İkili r & Kısmi r \\
Değişken & $\begin{array}{l}\text { Değişken } \\
\text { Sabit }\end{array}$ & 18,447 & 1,921 & - & 9,602 &, 000 & - & \\
& K.I. &, 091 &, 092 &, 070 &, 992 &, 322 &, 568 &, 050 \\
T.S.A. & I.I. & 1,365 &, 163 &, 591 & 8,351 &, 000 &, 650 &, 385 \\
\hline
\end{tabular}

$\mathrm{R}=0,651 \quad \mathrm{R} 2=0,423$

$\mathrm{F}(2,400)=146,914 \mathrm{p}=, 000$

\section{t-testi Sonuçları}

Öğrencilerin turizm sektörü algısına yönelik ölçek puanlarının cinsiyete göre t-testi sonuçları Tablo 9'de gösterilmiştir.

H2:Öğrencilerin turizm sektörü algısı ölçeğine verdikleri cevaplar cinsiyet değişkenine göre farkl1lık göstermekte midir?

Tablo 9'da de görüleceği üzere öğrencilerin turizm algısı ölçeğine verdikleri cevaplar cinsiyet faktörüne göre anlamlı bir farklılık göstermemektedir. T-Testi sonuçlarının yer aldığı tabloda da görüldü̆̆̈ü gibi, kadın ve erkek öğrencilerin Turizm Sektörü Algısı ölçeğine verdikleri cevaplar arasında anlamlı bir farklılık bulunmamaktadır. $F=(1,580)=3,238, p>0,05$. Yapılan test sonuçlarına göre, kadın öğrenciler ile $(X=48.2)$, erkek öğrencilerin benzer cevaplar verdikleri belirlenmiştir. ( $X=48.1)$. H2 Kabul edilmemiştir.

Tablo 9. Turizm Sektörü Algısına Yönelik Tutum Ölçeği Puanlarının Cinsiyete Göre t-testi Sonuçları.

\begin{tabular}{lllllll}
\hline Cinsiyet & $\mathrm{N}$ & $\mathrm{X}$ & $\mathrm{S}$ & $\mathrm{Sd}$ & $\mathrm{T}$ & $\mathrm{P}$ \\
Kadın & 172 & 48,2 & 13,45 & 401 & 0,10 &, 992 \\
Erkek & 231 & 48,1 & 12,99 & & & \\
\hline
\end{tabular}

\section{Anova Analiz Sonuçları}

Araştırmanın hipotezleri ve analizi sonuçları aşağıda değerlendirilmektedir. Bu bölümde üç adet hipotez oluşturulmuş ve analize tabi tutulmuştur.

H3:Öğrencilerin Turizm Sektörü Algıları ile okudukları bölüm arasında anlamlı bir ilişki var midir?

Araştırmaya katılan öğrencilerin turizm sektörü alg1sı ölçeğine verdikleri cevapların, okudukları bölüme göre betimsel istatistikleri aşağıdaki tabloda verilmektedir. Analiz sonuçlarına göre öğrencilerin turizm sektörü algısı ölçeğine verdiği cevaplar okudukları bölüme göre anlamlı bir şekilde değişmektedir. Farkların hangi gruplar arasında olduğunu bulmak amacıyla Scheffe testi yapılmıştır. Seyahat İşletmeciliği $(X=51,70)$ bölümünde okuyan öğrencilerin, Konaklama İşletmeciliği $(X=4,21)$ bölümünde okuyan öğrencilere göre turizm 
sektörü alg1sı ölçeğine daha olumlu yanıtlar verdiği görülmüştür. $F=(2,400)=6,13, p \leq 0,05$. H3 Kabul edilmiştir.

Tablo 10. Turizm Sektörü Algısı Ölçeğinin Betimsel İstatistikleri.

\begin{tabular}{clccc}
\hline \multirow{2}{*}{ Ölçek } & \multicolumn{1}{c}{ Bölüm } & $\mathbf{N}$ & $\mathbf{X}$ & Standart Sapma \\
& Konaklama İşletmeciliği & 217 & 46,21 & 13,37 \\
\multirow{3}{*}{ T.S.A } & Turizm Rehberliği & 99 & 49,45 & 11,64 \\
& Seyahat İşletmeciliği & 87 & 51,70 & 13,53 \\
& Total & 403 & 48,19 & 13,17 \\
\hline
\end{tabular}

Tablo 11. Turizm Sektörü Algısı Ölçeği Puanlarının Öğrencilerin Okuduğu Bölüme Göre ANOVA Sonuçları.

\begin{tabular}{lllllll}
\hline $\begin{array}{l}\text { Varyansin } \\
\text { kaynağ1 }\end{array}$ & Kareler toplamı & Sd & $\begin{array}{l}\text { Kareler } \\
\text { ortalaması }\end{array}$ & F & P & $\begin{array}{l}\text { Anlamlı } \\
\text { Fark }\end{array}$ \\
$\begin{array}{llll}\text { Gruplararası } \\
\text { Grup İçi }\end{array}$ & 2075,918 & 2 & 1037,959 & 6,131 &, 002 & $\begin{array}{l}\text { Sey.işl-kon } \\
\text { işl. }\end{array}$ \\
Toplam & 67721,596 & 400 & 169,304 & & & \\
\hline
\end{tabular}

H4:Öğrencilerin Turizm Sektörü Algıları ile okudukları sınıf arasında anlamlı bir ilişki var midir?

Ölçeklerin betimsel istatistikleri Tablo 12'de gösterilmektedir. Anova sonuçlarının yer aldığ tabloda da görüldüğü gibi 4.sınıf öğrencileri ile 2.Sınıf öğrencilerinin Turizm Sektörü Algısı ölçeğine verdikleri cevaplar arasında anlamlı bir farklılık bulunmaktadır. $F=(3,399)=3,238$, $p \leq 0,05$. Yapılan scheffe testi sonuçlarına göre, 2. Sınıf öğrencilerinin $(X=51.1)$, 4.sınıf öğrencilerinden daha olumlu cevaplar verdikleri belirlenmiştir. $(X=46.6)$. H4 Kabul edilmiştir.

Tablo 12. Turizm Sektörü Algısı Ölçeğinin Betimsel İstatistikleri.

\begin{tabular}{ccccc}
\hline & $\mathrm{N}$ & Ortalama & Standart Sapma \\
& 1.Sinif & 83 & 48,4 & 11,95 \\
\multirow{3}{*}{ T.S.A } & 2.Sinif & 113 & 51,1 & 13,49 \\
& 3.Sinif & 65 & 45,9 & 15,19 \\
& 4. Sinif & 142 & 46,6 & 12,27 \\
& Total & 403 & 48,1 & 13,17 \\
\hline
\end{tabular}

Tablo 13. Turizm Sektörü Algısı, Kariyer İyimserliği, İş Güvencesizliği Ölçeği Puanlarının Öğrencilerin Okuduğu Sınıfa Göre ANOVA Sonuçları.

\begin{tabular}{lllllll}
\hline & Kareler Toplamı & Sd & Kareler Ortalaması & F & P & Anlamlı Fark \\
Gruplararası & 1658,841 & 3 & 552,947 & 3,238 &, 022 & 2.sınıf-4.sınıf \\
. Gruplariçi & 68138,672 & 399 & 170,774 & & & \\
Toplam & 69797,514 & 402 & & & & \\
\hline
\end{tabular}

H5:Öğrencilerin turizm sektörü algıları ve çalışma süreleri arasında anlamlı bir ilişki var midir?

Katılımcıların turizm sektörü algıları ve çalışma süreleri arasında anlamlı bir farklılık saptanmamıştır. $F=(3,399)=2,202, p \leq 0,05$. Yapılan scheffe testi sonuçlarına göre, çalışmayan bireyler $(X=48,4) 1-12$ ay arası çalışmış bireyler $(X=51,1), 13-24$ ay arası çalışmış bireyler $X=45,9), 2$ yıl ve üzeri çalışmış bireyler ise $(X=46.6)$ olarak hesaplanmaktadır. H5 Kabul edilmemiştir. 
Tablo 14. Turizm Sektörü Algısı Betimsel İstatistikleri

\begin{tabular}{cccc}
\hline & N & Ortalama & Standart Sapma \\
Çalışmadım & 83 & 48,4 & 11,95 \\
1-12 Ay arası & 113 & 51,1 & 13,49 \\
T.S.A13-24 Ay arası & 65 & 45,9 & 15,19 \\
2 Yıl ve üzeri & 142 & 46,6 & 12,27 \\
Toplam & 403 & 48,1 & 13,17 \\
\hline
\end{tabular}

Tablo 15. Turizm Sektörü Algısı Ölçeği Puanlarının Bireylerin Çalışma Sürelerine Göre

\begin{tabular}{llccccc}
\multicolumn{8}{c}{ ANOVA Sonuçları } \\
\hline & Kareler Toplamı & Sd & Kareler Ortalaması & Anl. & Anlamlı Fark \\
T.S.A. Gruplararası & 1136,920 & 3 & 378,973 & 2,202 &, 087 \\
& Grupiçi & 68660,594 & 399 & 172,082 & & \\
Toplam & 69797,514 & 402 & & & \\
\hline
\end{tabular}

\section{Sonuç ve Öneriler}

Turizmin, hizmet sektörü içerisinde yer alan ve tüm ülkelerin pay almaya çalıştığ 1 bir sektör olduğu açık olarak görülmektedir. Yoğun rekabet ortamında ayakta kalabilmek için müşteri memnuniyeti, kalite gibi hayati önem taşıyan konular ön planda olmalıdır ki bu da turizm sektörü çalışanlarıyla doğrudan alakalıdır. Terör, doğal afetler, ekonomik dalgalanmalar sonucu, ülkeler arası siyasi gerginlikler gibi olaylardan turizm sektörü çok kolay etkilenebilir ve turizm talebi azalabilir. Bu durumdan ilk olarak etkilenenlerin işletme çalışanları olduğunu söyleyebiliriz. Turizm sektöründe maliyetleri kısmak amacıyla, çalışanları ücretsiz izine ayırma ya da işten çıkarma sık sık görülmektedir. Bir diğer konu da özellikle yılın belli zamanları açık olan yani mevsimlik çalışan işletmelerde, sezon bittiği zaman çalışanların çoğunluğu işten çıkarılmaktadır. Bu gibi durumlar çalışanlarda iş güvensizliğine ve kariyer iyimserliğinde azalmaya neden olmaktadır.

Araştırma hipotezlerinin sonuçlarına göre, turizm öğrencilerinin turizm sektörü algısıyla, iş güvencesizliği arasında pozitif ve orta düzeyde bir korelasyonun olduğu görülmektedir. Ancak turizm sektörü algısı ve kariyer iyimserliği arasında anlamlı bir ilişki olmadığ görülmektedir. Buradan, örneklemi oluşturan öğrencilerin iş güvencesizliği ile ilgili düşüncelerinin, turizm sektörü ile ilgili algılarını etkilediğini, ancak kariyer iyimserliklerinin turizm sektörü ile ilgili düşüncelerini etkilemediği anlaşılmaktadır. Diğer bir ifade ile iş güvencesizliği, öğrencilerin turizm sektörüne bakışını olumsuz yönde etkilemektedir. Diğer hipotez sonuçlarına göre ise, seyahat işletmeciliği bölümünde okuyan öğrencilerin, konaklama işletmeciliği bölümünde okuyan öğrencilere göre ve 2. Sınıf öğrencilerinin de, 4.sınıf öğrencilerine göre turizm sektörü algısı ölçeğine daha olumlu yanıtlar verdiği görülmektedir. Bu durumu 4. Sınıf öğrencilerinin, sektörde 2. Sınıf öğrencilerine göre daha fazla sektör hakkında bilgi ve tecrübeye sahip olmaları nedeniyle olumsuz bakış açısı geliştirmiş olmaları ile açıklamamız mümkündür. Konaklama işletmeciliği öğrencilerinin, seyahat işletmeciliği öğrencilerine göre daha olumsuz cevaplar vermeleri ise, konaklama işletmelerinde çalışma ortamının daha zor olarak algılanması ile açıklanabilmektedir. Yine hipotez sonuçlarına göre, öğrencilerin turizm algısı ölçeğine verdikleri cevaplar cinsiyet faktörüne göre anlamlı bir farklılık göstermemektedir. 
Literatür çalışmasından da ortaya konduğu gibi, iş güvencesi turizm sektöründe oldukça önem taşımaktadır. Çalışanın iş güvencesine sahip olmadığını düşünmesi özel ve iş yaşamında olumsuzluklar yaratmakta, bu durum kişiyi olumsuz etkileyeceği gibi işletme içinde verimsizlik yaratmaktadır. Turizm işletmelerinin hizmet sektörü olması nedeniyle, çalışanların iş güvencesine sahip olması diğer sektörlere göre bir nebze daha önem taşımaktadır. Turizm sektöründe müşteri memnuniyetinin, ilk olarak çalışanlarla alakalı olduğunu söylemek mümkündür. Bu çalışma çerçevesinde elde edinen sonuçta, geleceğin turizm çalışanları olan turizm öğrencilerinin turizm sektörü algısının, iş güvencesinden orta düzeyde ve pozitif etkilendiği sonucu ortaya çıarmaktadır. Örneklemin, turizm sektöründe çalışmış olduğu da göz önüne alındığında bu sonuç oldukça önemlidir. Veriler doğrultusunda, turizm işletmelerinin çalışanlarına iş güvencesi sağlanmasının turizm sektörü algısını olumlu etkileyeceğini dolayısıyla sonuçta turizm işletmelerine verimli çalışma olarak geri döneceğini söylememiz mümkündür.

Bir diğer önemli sonuç olan, 4. Sınıf öğrencilerinin, 2. Sınıf öğrencilerine oranla turizm sektörü algısı ölçeğine olumsuz yanıt vermeleri sektörde yaşanan olumsuz tecrübelere dayandırılabilir. Diğer bir ifade ile 4. sınıf öğrencilerinin, 2. Sınıf öğrencilerine oranla sektörde daha fazla deneyim sahibi olmaları bu sonuca neden olmuş olabilir. Bir diğer önemli sonuçta, konaklama işletmeciliği öğrencilerinin seyahat işletmeciliği öğrencilerine göre turizm sektörünü daha olumsuz algılamalarıdır. Konaklama işletmelerinin sayı ve çeşit olarak, seyahat işletmelerine oranla daha fazla olması, farklı yönetim tarzı olan işletme sayısının daha fazla olmasına neden olabilir. Bu durum farklı yönetim tarzlarında yaşanan olumsuzlukların daha fazla olması ile açıklanabilir.

\section{Hipotezlerin Sonuçları}

\begin{tabular}{|l|l|l|}
\hline & Hipotez & Sonuç \\
\hline 1 & $\begin{array}{l}\text { İş güvencesizliği ve kariyer iyimserliği, turizm sektörü algısını anlamlı } \\
\text { bir şekilde etkilemekte midir? }\end{array}$ & Etkilemektedir. \\
\hline & Kariyer iyimserliği turizm sektörü algısını etkilemekte midir? & Etkilememektedir. \\
\hline 2 & $\begin{array}{l}\text { Öğrencilerin turizm sektörü algısı ölçeğine verdikleri cevaplar cinsiyet } \\
\text { değişkenine göre farklılık göstermekte midir? }\end{array}$ & Kabul edilmedi. \\
\hline 3 & $\begin{array}{l}\text { Öğgrencilerin turizm sektörü algıları ile okudukları bölüm arasında } \\
\text { anlamlı bir ilişki var mıdır? }\end{array}$ & Kabul edildi. \\
\hline 4 & $\begin{array}{l}\text { Öğrencilerin turizm sektörü algıları ile okudukları sınıf arasında } \\
\text { anlamlı bir ilişki var mıdır? }\end{array}$ & Kabul edildi. \\
\hline 5 & $\begin{array}{l}\text { Öğrencilerin turizm sektörü algıları ve çalışma süreleri arasında } \\
\text { anlamlı bir ilişki var mıdır? }\end{array}$ & Kabul edilmedi. \\
\hline
\end{tabular}

\section{Kaynakça}

Aaker, D.A., Kumar,V. ve Day, G.S. (2007). Marketing Research, 9. Edition, John Wiley \&Sons, Danvers.

Aymankuy, Y. ve Aymankuy, Ş. (2013). “Turizm İşletmeciliği Eğitimi Alan Öğrencilerin Turizm Sektöründeki İstihdamla İlgili Görüşleri Ve Sektördeki Kariyer Beklentileri" (Balıkesir Üniversitesi Turizm İşletmeciliği ve Otelcilik Yüksekokulu Örneği), Akademik Bakış Dergisi, 35, 1-21. 
Bakan İ. ve Büyükbeşe T. (2004), “Örgütsel İletişim İle İş Tatmini Unsurları Arasındaki İlişkiler: Akademik Örgütler İçin Bir Alan Araştırması", Akdeniz İIBf Dergisi Sayı: 7 Sayfa:130.

Baruch, Y. (2004). Managing Careers Theory And Practice, Prentice Hall, London

Baum, T. (2007), "Human Resources in Tourism:Stil Waiting For Change", Tourism Management, Vol.28, Pp.1383-1399.

Burgard, S. A., Brand, J. E. And House, J. S. (2008), "Perceived Job Insecurity And Worker Health

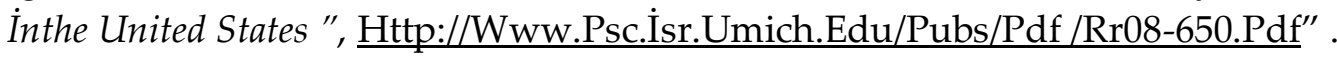

Büyüköztürk, Ş. (2010). Sosyal Bilimler İçin Veri Analizi El Kitabı, Pegem Akademi Yayıncılık, Ankara.

Bingöl, D. (2003). İnsan Kaynakları Yönetimi, İstanbul 5. Baskı, Beta Yayınevi.

Can, H., Akgün, A. ve Kavuncubaşı S. (1998). Kamu ve Özel Kesimde İnsan Kaynakları Yönetimi, 4.Bask1, Siyasal Kitabevi, Ankara.

Carver C.S. ve Scheier, M.F. (1998), Optimism, Coping, And Health: Assessment And Implications Of Generalized Outcome Expectancies. Health Psychology 4 (3), 219.

Çakır, Ö. (2007), "İşini Kaybetme Kaygısı: İş Güvencesizliği”, Çalışma ve Toplum Dergisi", Ss.117-140.

Çatır O. ve Karaçor, M. (2016). “İnsan Kaynaklarında Kariyer Planlama: Turizm Öğrencileri Üzerine Bir Alan Araştırması", Çatalhöyük, Uluslararası Turizm Ve Sosyal Araştırmalar Dergisi, 201-220.

Dawson, M., Abbott, J., Shoemaker (2011). The Hospitality Culture Scale: A Measure Of Organizational Culture And Personal Attributes. International Journal Of Hospitality Manegement, 30(2)290-300.

Duman. T., Tepeci, M. ve Unur, K. (2006). Mersin'de Yükseköğretim Ve Orta Öğretim Düzeyinde Turizm Eğitimi Almakta Olan Öğrencilerin Sektörün Çalışma Koşullarını Algılamaları Ve Sektörde Çalışma İsteklerinin Karşılaştırmalı Analizi, Anatolia: Turizm Araştırmaları Dergisi, 17(1), 51- 69.

Dursun, S. ve Bayram, N. (2013), "İş, Güç" Endüstri İlişkileri Ve İnsan Kaynakları Dergisi İş Güvencesizliği Algısının Çalışanların Kaygı Düzeyleri Üzerine Etkisi: Bir Uygulama, Temmuz/July 2013, Cilt/Vol: 15, Sayı/Num: 3, Page: 20-27 Issn: 1303-2860.

Erlinghagen, M. (2008), “Self-Perceived Job Insecurity And Social Context: A Multi-Level Analysis Of 17 European Countries", European Sociological Review, 24(2), 183-197

Geers A. L., Wellman, J. A. \& Lassiter, G. D. (2009). Dispositional Optimism And Engagement: The Moderating Influence Of Goal Prioritization, Journal Of Personality And Social Psychology, 96 (4), 913-932.

Gençoğlu, C., Alkan, E., Koçyiğit, M. (2014). Bir Mit Olarak İyimserlik, Kızlar Mı Erkekler Mi Daha İyimser?, Elektronik Sosyal Bilimler Dergisi, Yaz-2014 Cilt:13 Sayı:50 (129-138).

Güler, B. K., \& Emeç, H. (2006). Yaşam Memnuniyeti Ve Akademik Başarıda İyimserlik Etkisi. D.E.Ü.I.I.̇.F. Dergisi, 2 (2), 129-149.

Güler, N. (2012). Eğitimde Ölçme Ve Değerlendirme. (3. Baskı). Ankara: Pegema Yayıncllık. 
Gürbüz, Said Ve Yüksel, Murad (2008), "Çalışma Ortamında Duygusal Zekâ: İş Performansı, İş Tatmini, Örgütsel Vatandaşlık Davranışı Ve Bazı Demografik Özelliklerle İlişsisi”, Doğuş Üniversitesi Dergisi, 9 (2), 174-190.

Hacıoğlu, N. (2010). Turizm Pazarlaması, 7.Baskı, Ankara: Nobel Yayınevi.

Halıcı, A., Delil, Y., (2003).“Büro Yönetimi Öğrencilerinin Mesleki Algılarının Belirlenmesine Yönelik Bir Uygulama”, Gazi Üniversitesi Ticaret Ve Turizm Ĕ̆itim Fakültesi Dergisi, S.1, S.2237.

Heaney, Israel Ve House (1994), Chronic Job İnsecurity Among Automobile Workers: Effects On Job Satisfaction And Health. Social Science \& Medicine, 38, 1431-1437.

Www2.Unwto.Org/Press-Release/2019-01-21/İnternational-Tourist-Arrivals-Reach-14-BillionTwo-Years-Ahead-Forecasts

Kalafat, T. (2016). Kariyer Geleceği Ölçeği (Kargel): Türk Örneklemi İçin Psikometrik Özelliklerinin İncelenmesi. Türk Psikolojik Danışma Ve Rehberlik Dergisi, 4(38).

Karacaoğlu K. (2015) “Çalışanların İş Güvencesizliğinin İşten Ayrılma Niyetleri Üzerindeki Etkisi: Alanya Bölgesindeki Beş Yıldızlı Otellerde Bir Araştırma” Uluslararası Alanya İşletme Fakültesi Dergisi. Y1l:2015, C:7, S:1, S. 13-21.

Kluemper, Little, D.H., Ve Degroot, T. (2009). State Or Trait: Effects Of State Optimism On Job-Related Outcomes. Journal Of Organizational Behavior, 30, 209-231.

Kozak, M.A, (1999). Konaklama Sektöründe Kariyer Planlama Yöntemleri Ve Uygulamada Karşılaşılan Sorunlar Üzerine Bir Araştırma, Anatolia: Turizm Araştırmaları Dergisi, (10), 916.

Kulaksızloğlu, A., Dilmaç, B., Ekşi, H. Ve Otrar M. (2003). Uyum Ölçeği-Üniversite Formu'nun Dilsel Eşdeğerlik, Geçerlik Ve Güvenirlik Çalışması. Eğitim Bilimleri Ve Uygulama, 2 (3), 4963.

Kusluvan, S. Ve Kusluvan, Z. (2000). Perceptions And Attitudes Of Undergraduate Tourism Students Towards Working İn The Tourism Industry In Turkey, Tourism Management, 21: 251-269.

O'leary, S. Ve Deegan, J. (2005). Careerprogression Of Trishtourismandhospitality Management Graduates, International Journal Of Contemporaryhospitality Management, 17(5), 421-432.

Özdamar K., (2002). Paket Programlar İle İstatistik Veri Analizi, Eskişehir: Kaan Kitapevi, 661673.

Özgen H.,Öztürk A., Yalçın A., (2002). İnsan Kaynakları Yönetimi, Nobel Kitabevi, Adana.

Özyaman, F.B. (2007), Hemşirelerde İş Güvencesi Algısı Ve Anksiyete Ve Depresyon Düzeylerinde Etkisi, İş Sağlığı Doktora Tezi, Dokuz Eylül Üniversitesi Sağlık Bilimleri Enstitüsü, S.3.

Patton Ve Mcmahon, (2006), The Systems Theory Framework Of Career Development And Counseling: Connecting Theory And Practice, International Journal For The Advancement Of Counselling June 2006,Volume 28,Issue2,s 153-166।.

Pehlivan, H. (1994). Eğitim Bilimleri Öğrencilerinin Öğrenim Gördükleri Bölümlere Yönelik Tutumları, Hacettepe Üniversitesi Ĕ̆itim Fakültesi Dergisi, 10, 49-53. 
Poyraz K. ve Kama B. (2008). Algılanan İş Güvencesinin, İş Tatmini, Örgütsel Bağlılık Ve İşten Ayrılma Niyeti Üzerindeki Etkilerinin İncelenmesi. Süleyman Demirel Üniversitesi İktisadi Ve İdari Bilimler Fakültesi 13 (2), 143-164.

Rottinghaus, P. J., Day, S. X., ve Borgen, F. H.(2005). The Career Futures Inventory: A Measure Of Career-Related Adaptability And Optimism. Journal Of Career Assessment, 13 (1), 3-24.

Savickas, M. L. (1990). The Use Of Career Choice Measures In Counseling Practice. Testing In Counseling Practice, 373-417.

Scheier, M. E. ve Carver, C. S. (1987). Dispositional Optimism And Physical Well-Being: The Influence Of Generalized Outcome Expectancies On Health. Journal Cf Personality, 55 (2), 170210.

Seçer, B. (2011), “İş Güvencesizliğinin İçsel İşten Ayrılma Ve Yaşam Doyumuna Etkisi”, İşgü̈ç Endüstri Iliş̧kileri Dergisi, Cilt:13, Sayı:4.

Seligman, M. (2006). Learned Optimism: How To Change Your Mind And Your Life, Switzerland, Random House.

Tavşancıl, E.(2002). Tutumların Ölçülmesi Ve Spss Veri Analizi, Nobel Yayınevi, Ankara.

Türkay, O. ve Eryılmaz, B. (2014). Kariyer Değerleri Ve Kariyer Yolu Tercihleri İlişkisi: Türk Turizm Sektöründen Örnekler, Muğla Üniversitesi Sosyal Bilimler Enstitüsü Dergisi (İlke), (24), 179- 200.

Ulama, Ş., Batman, O. ve Ulama, H. (2015), “Lisans Düzeyinde Turizm Eğitimi Alan Öğrencilerin Kariyer Algılamalarına Yönelik Bir Araştırma: Sakarya Üniversitesi Örneği", Bartın Üniversitesi İ.İ.B.F. Dergisi, 6 (12). 339-366.

Uma, S. (1992). Research Methods For Busines, 2.Th Edition, John Wiley \& Sons,U.S.A.

Ünlüönen, K. ve Boylu, Y. (2005). “Türkiye’de Yükseköğretim Düzeyinde Turizm Eğitimindeki Gelişmelerin Değerlendirilmesi", Elektronik Sosyal Bilimler Dergisi, 3(12), 11 32. 